\title{
About the Lincoln Institute
}

The Lincoln Institute of Land Policy is a nonprofit and tax-exempt educational institution established in 1974. Its mission as a school is to study and teach land policy, including land economics and land taxation. The Institute is supported primarily by the Lincoln Foundation, which was established in 1947 by Cleveland industrialist John C. Lincoln. He drew inspiration from the ideas of Henry George, the nineteenth-century American political economist, social philosopher and author of the book, Progress and Poverty.

The Institute's goals are to integrate theory and practice to better shape land policy and to share understanding about the multidisciplinary forces that influence public policy. The Institute organizes its work in two departments: valuation and taxation, and planning and development. In addition we support a program on Latin American and Caribbean studies.

The Lincoln Institute seeks to improve the quality of debate and disseminate knowledge of critical issues in land policy by bringing together scholars, policy makers, practitioners and citizens with diverse backgrounds and experience. We study, exchange insights and work toward a broader understanding of complex land and tax policies. The Institute does not take a particular point of view, but rather serves as a catalyst to facilitate analysis and discussion of these issues - to make a difference today and to help policy makers plan for tomorrow. 